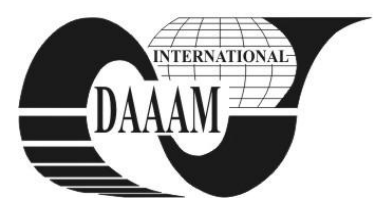

\title{
ASSESSMENT OF ENVIRONMENTAL IMPACTS OF THE POST-DRILL CLEANING PROCESS FOR PCB USING LCA
}

\author{
LEE, G[yu] B[ong] \& KO, M[injae]
}

\begin{abstract}
In this study, assessment of quantitative environmental impacts was performed for the cleaning process for PCB by using a LCA method, which is regarded as a useful tool for analyzing diverse environmental impacts at a local, regional, and global aspect. According to three geological aspects, environmental impacts were categorized into ten types. For these impact categories, characterization was carried out for evaluating environmental burdens of the cleaning process under consideration. Then, normalization was done in order to obtain a better understanding of the relative size among impact categories.
\end{abstract}

Keywords: PCB cleaning process, Environmental impact, Life Cycle Assessment(LCA), inventory analysis, impact assessment

\section{INTRODUCTION}

Increased public awareness of the threats posed by global warming has led to greater concern over the impact of anthropogenic carbon emissions on the global climate. The current level of carbon dioxide $\left(\mathrm{CO}_{2}\right)$ in the atmosphere is approaching $380 \mathrm{ppm}[1]$, higher than 350 ppm to be assumed as the safest value. Without technological and societal changes the level is projected to increase to over $800 \mathrm{ppm}$ by the end of the century[2].

Environmental life cycle assessment (LCA) is a valuable tool for understanding and improving the environmental hazards posed during life cycle of a product. In addition it allows producers to optimize the manufacturing process with reduction of adverse environmental impacts. In this study, LCA method is applied to a cleaning process of a company in charge of some processes required to manufacture Printed Circuit Board (PCB) in Korea. Procedure is proposed to assess environmental load factors through environmental impact assessment about the cleaning process and to utilize them to improve the process in the viewpoint of environment.

\section{INFORMATION OF LCA}

\subsection{Concept of LCA}

LCA technique requires lists of inputs and outputs associated with life cycle of a system to assess the potential environmental impacts related to product, service, and process. Material and energy used for them and pollutants produced by them are investigated and quantified to realize them environmentally healthy and sustainable through the LCA. In other words, some opportunities for environmental improvement are searched and assessed by evaluating the environmental problems such as global warming or resource depletion. The LCA consists of 4 phases as follows[3]:

(1) Definition of goal and scope
In order to make efficient use of time and resources, the following 6 decisions must be made at the beginning of the LCA : (1) define the goal of the project, (2) determine what type of information is needed to inform the decision-makers, (3) determine the required specificity, (4) determine how the data should be organized and the results displayed, (5) define the scope of the study, (6) determine the ground rules for performing the work[4].

\section{(2) Inventory analysis}

Life cycle inventory (LCI) involves data collection and modeling of the system as well as description and verification of data. This encompasses the environmental and technical data related to all processes that compose the system.

\section{(3) Impact assessment}

This phase of LCA is aimed at evaluating the significance of potential environmental impacts based on the results of the LCI analysis. This is accomplished through four steps; classification, characterization, normalization, and weighting. Each step is classified into mandatory and optional elements[5].

\section{(4) Interpretation}

Life cycle interpretation is a systematic technique to identify, quantify, check, and evaluate information obtained from the results of previous phases. The results from the inventory analysis and impact assessment are summarized during this phase. The outcome of the interpretation phase is a set of conclusions and recommendations for the study[6].

\subsection{Research trends of LCA}

LCA is a technical foundation of environmental labeling, environmental performance evaluation, and environmental standard being discussed actively as a core project in the field of environmental management. Studies on LCA had begun in United States and Europe since the 1960s. At that time, it was mainly utilized to evaluate energy consumption of materials for packaging. After that, studies on LCA had been started in earnest as one of ways to prospect efficient usage of the limited energy and systematic supply of the depleted natural resources.

In 1969, Coca-Cola Company performed the research targeted at the beverage containers to compare and analyze emission of pollutants and consumption of natural resources. The research formed the basis of Life Cycle Inventory Analysis (LCIA). In the late 1980s, the recycling efforts had been started as the solid waste 
problems came to the fore internationally with increased concern about serious pollution of air and water. As a result, LCA emerged as a new tool for analyzing the environmental issues.

In the early 1990s, the guideline and database of LCA to be used at the public and private sectors were developed as studies on the specific methodology of LCA started by the Society of Environmental Toxicology and Chemistry (SETAC) and the U.S. Environmental Protection Agency (EPA). In the late 1990s, the International Organization for Standardization (ISO) announced the environmental management standard (ISO-14000 series) used throughout the world, which provoked researches and applications of LCA to be performed extensively by nations, industries, and companies[7].

\section{LCA OF THE POST-DRILL CLEANING PROCESS FOR PCB}

\subsection{Definition of goal and scope}

PCB is primary component in most electric devices used to mechanically support and electrically connect circuit way. PCB is manufactured by means of several processes composed of scrubbing, developing, drilling, plating, etc. Drilling is to make interconnection holes between adjacent layers and via holes within a layer for fabrication of multi-layer circuit board by using a drill machine.

The post-drill cleaning process can be divided into pressurized water cleaning process and heat drying process as shown in Fig. 1. The contaminants such as chips, debris, and finger print occurred during drilling are removed through the pressurized water cleaning process by using fresh water. Moisture remained after the water cleaning process is drained thoroughly during the heat drying process where the multi stage blowers spray hot air through four air knives. The aim of this paper is to assess environmental impacts and contributions by quantifying the environmental load from two processes. In other words, the evaluation methods to be used for decision-making to improve processes are proposed with the basic information to evaluate a comprehensive environmental load.

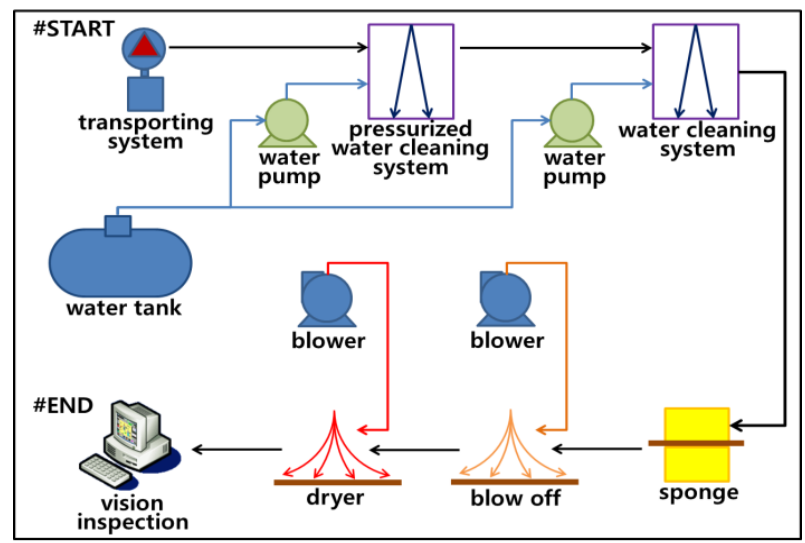

Fig. 1. Workflow diagram of post-drill cleaning process

In order to perform LCA, input and output data related to the materials and energy used for the target processes should be collected after data categories such as air pollutants, water pollutants, and wastes (for example, sludge and heavy metals in sludge) are identified according to research purpose in advance. Tab. 1 shows the key information required for SimaPro, a software tool for LCA. Data of energy consumption and interior temperature are measured in real time by means of electric power meter and temperature controller installed on the post-drill cleaning sytem of a company in Korea as shown in Fig. 2.

\begin{tabular}{|c|c|c|c|c|c|}
\hline \multirow{2}{*}{$\begin{array}{c}\text { Process } \\
\text { Name }\end{array}$} & \multirow[b]{2}{*}{ Unit } & \multicolumn{2}{|c|}{ Input } & \multicolumn{2}{|c|}{ Output } \\
\hline & & Item & Quantity & Item & $\begin{array}{c}\text { Quant } \\
\text { ity }\end{array}$ \\
\hline \multirow{4}{*}{$\begin{array}{c}\text { Pressurized } \\
\text { water } \\
\text { cleaning } \\
\text { process }\end{array}$} & \multirow[t]{2}{*}{$\begin{array}{c}\text { liter, } \\
\mathrm{kg}\end{array}$} & \multirow[t]{2}{*}{$\begin{array}{l}\text { fresh } \\
\text { water }\end{array}$} & \multirow[t]{2}{*}{104} & $\begin{array}{c}\text { pollute } \\
\mathrm{d} \\
\text { water }\end{array}$ & 104 \\
\hline & & & & wastes & 0.006 \\
\hline & $\mathrm{kWh}$ & $\begin{array}{l}\text { electric } \\
\text { power }\end{array}$ & 74 & - & - \\
\hline & $\begin{array}{c}\mathrm{kg} / \mathrm{c} \\
\mathrm{m}^{2}\end{array}$ & $\begin{array}{c}\text { water } \\
\text { pressure }\end{array}$ & 5 & - & - \\
\hline \multirow{2}{*}{$\begin{array}{c}\text { Heat } \\
\text { drying } \\
\text { process }\end{array}$} & ${ }^{\circ} \mathrm{C}$ & hot air & 88 & - & - \\
\hline & $\mathrm{kWh}$ & $\begin{array}{l}\text { electric } \\
\text { power }\end{array}$ & 150 & - & - \\
\hline
\end{tabular}

Tab. 1. Key information for SimaPro software tool

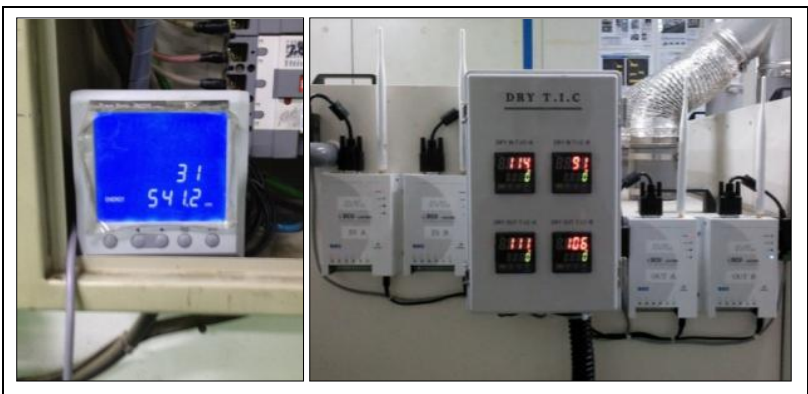

Fig. 2. Electric power meter and temperature controller

\subsection{Inventory analysis}

Fig. 3 shows a result of inventory analysis of the pressurized water cleaning process. The LCI helps to understand which process components and parameters affect the environmental impact. The LCI not only describes the energy and material streams, but also clarifies potential levers for improving process sustainability[8].

\subsection{Impact assessment}

LCA was performed through 3 steps of classification, characterization, and normalization to understand the potential environmental impacts of the post-drill cleaning process using SimaPro.

\section{(1) Classification}

The factors derived from inventory analysis are classified by the impact categories. Namely, classification shows the forms of effect on the environment by inventory items. Generally, the following impact categories are considered; abiotic resource depletion, global warming, ozone layer depletion, acidification, eutrophication, photochemical oxidant formation, ecotoxicity, and human toxicity.

\section{(2) Characterization}

Effects on each impact category by the factors classified at the classification step are quantified in the characterization step. 


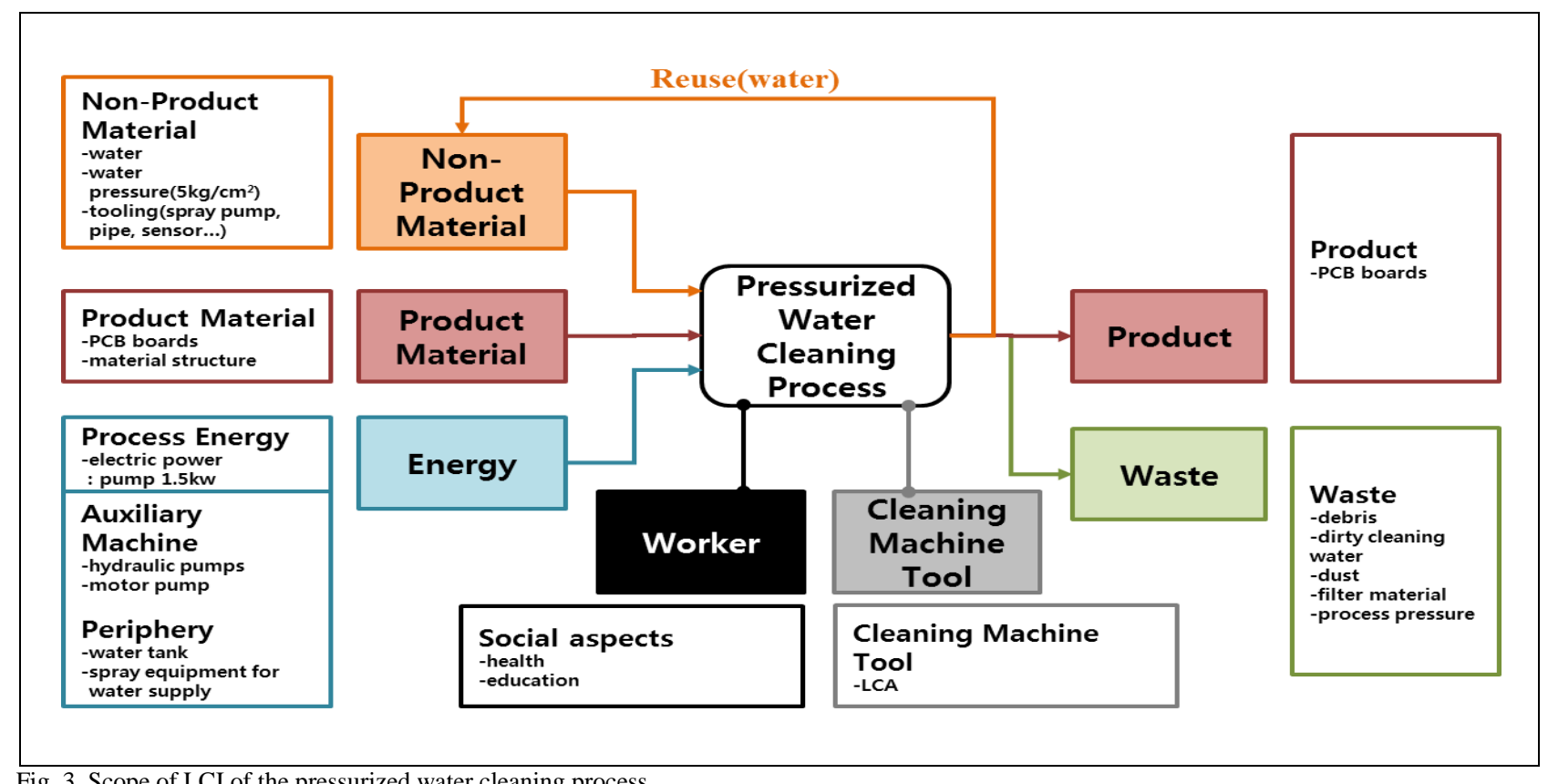

Fig. 3. Scope of LCI of the pressurized water cleaning process

As shown in Fig. 4, environmental impact potential by each impact category was different according to the attributes of each process. Pressurized water cleaning process is responsible for a sizable proportion of ecotoxicity categories, while the heat drying process contribues highly to the categories of global warming, ozone layer depletion, and human toxicity.

\section{(3) Normalization}

Normalization is performed to gain clear information about the relative size of environmental impacts. The value of environmental impact normalized by process is shown in Fig. 5. Total environmental impacts of the pressurized water cleaning process are unusually higher than those of the heat drying process. The impacts in the field of fresh water aquatic ecotoxicity (FAET) and marine aquatic ecotoxicity (MAET) are the highest, followed by terrestrial ecotoxicity (TET) in case of the cleaning process. In case of the drying process, the impacts in the field of MAET are the highest, followed by acidification and global warming.

\subsection{Interpretation}

As shown in Fig. 6, LCA analysis shows that more than $98 \%$ of FAET are arisen from the pressurized water cleaning process. Naturally, this phenomenon seems to be shown because much cleaning water is used and wastes like debris are emitted.

The assessment also shows that more than $70 \%$ of the other seven categories except FAET, MAET, and TET are affected by the heat drying process. The large quantities of electric power consumed for operating the machines and heating the oven system contribute to global warming, acidification, etc. Although it is very difficult to decrease the consumption of electric power in the existing post-drill cleaning system, ways to reduce the energy consumed and the environmental impacts should be taken through recycling of used water, prevention of thermal loss, regular frequent inspection of equipments, etc.

\begin{tabular}{|c|c|c|c|}
\hline \multicolumn{2}{|c|}{ Impact category } & Unit & Reference \\
\hline \multicolumn{2}{|c|}{$\begin{array}{l}\text { Abiotic Resources } \\
\text { Depletion (ARD) }\end{array}$} & $1 / \mathrm{yr}$ & $\begin{array}{l}\text { 1) IEA, International } \\
\text { Energy Annual } \\
2000,2002 \\
\text { 2) U.S. Geological } \\
\text { Survey(USGS) } \\
2001-2002\end{array}$ \\
\hline \multicolumn{2}{|c|}{ Acidification Potential(AP) } & $\mathrm{kg} \mathrm{SO}_{2}$-eq $/ \mathrm{kg}$ & $\begin{array}{l}\text { AP(Hauschild \& } \\
\text { Wenzel, 1998) }\end{array}$ \\
\hline \multicolumn{2}{|c|}{$\begin{array}{l}\text { Eutrophication } \\
\text { Potential(EP) }\end{array}$} & $\begin{array}{l}\mathrm{kg} \mathrm{PO}_{4}{ }^{3-} \\
\mathrm{eq} / \mathrm{kg}\end{array}$ & Heijung et al, 1992 \\
\hline \multicolumn{2}{|c|}{$\begin{array}{l}\text { Global Warming Potential } \\
\text { (GWP) }\end{array}$} & $\mathrm{kg} \mathrm{CO}-\mathrm{eq} / \mathrm{kg}$ & IPCC, 1996 \\
\hline \multicolumn{2}{|c|}{$\begin{array}{l}\text { Ozone Depletion Potential } \\
\text { (ODP) }\end{array}$} & $\begin{array}{l}\mathrm{kg} \mathrm{CFC}- \\
\mathrm{eq} / \mathrm{kg}\end{array}$ & UNEP, 2002 \\
\hline \multicolumn{2}{|c|}{$\begin{array}{l}\text { Photo-Chemical Oxidant } \\
\text { Creation Potential (POCP) }\end{array}$} & $\begin{array}{l}\mathrm{kgC}_{2} \mathrm{H}_{4}^{-} \\
\mathrm{eq} / \mathrm{kg}\end{array}$ & $\begin{array}{l}\text { POCP(Jenkin \& } \\
\text { Hayman, 1999: } \\
\text { Derwent et al. } 1998 \\
\text { : high Nox) }\end{array}$ \\
\hline \multirow{3}{*}{$\begin{array}{l}\text { Ecotoxicit } \\
\text { y } \\
\text { Potential }\end{array}$} & $\begin{array}{l}\text { Marine aquatic } \\
\text { Ecotoxicologic } \\
\text { al } \\
\text { Impacts(MAE } \\
\text { TP) }\end{array}$ & $\begin{array}{l}\text { kg } 1,4-\mathrm{DCB} \\
\text { eq./kg }\end{array}$ & $\begin{array}{l}\text { MAETP inf. } \\
\text { (Huijbregts, } 1999 \& \\
\text { 2000) }\end{array}$ \\
\hline & \begin{tabular}{|l|} 
Terrestrial \\
aquatic \\
Ecotoxicologic \\
al \\
Impacts(TETP)
\end{tabular} & $\begin{array}{l}\mathrm{kg} 1,4-\mathrm{DCB} \\
\text { eq./kg }\end{array}$ & $\begin{array}{l}\text { TETP inf. } \\
\text { (Huijbregts, } 1999 \& \\
\text { 2000) }\end{array}$ \\
\hline & $\begin{array}{l}\text { Fresh water } \\
\text { aquatic } \\
\text { Ecotoxicologic } \\
\text { al } \\
\text { Impacts(FAET } \\
\text { P) }\end{array}$ & $\begin{array}{l}\mathrm{kg} 1,4-\mathrm{DCB} \\
\text { eq./kg }\end{array}$ & $\begin{array}{l}\text { FAETP inf. } \\
\text { (Huijbregts, } 1999 \& \\
\text { 2000) }\end{array}$ \\
\hline \multicolumn{2}{|c|}{$\begin{array}{l}\text { Human Toxic } \\
\text { Potential(HTP) }\end{array}$} & $\begin{array}{l}\mathrm{kg} 1,4-\mathrm{DCB} \\
\text { eq./kg }\end{array}$ & $\begin{array}{l}\text { HTP inf. } \\
\text { (Huijbregts, } 1999 \text { \& } \\
\text { 2000) }\end{array}$ \\
\hline
\end{tabular}




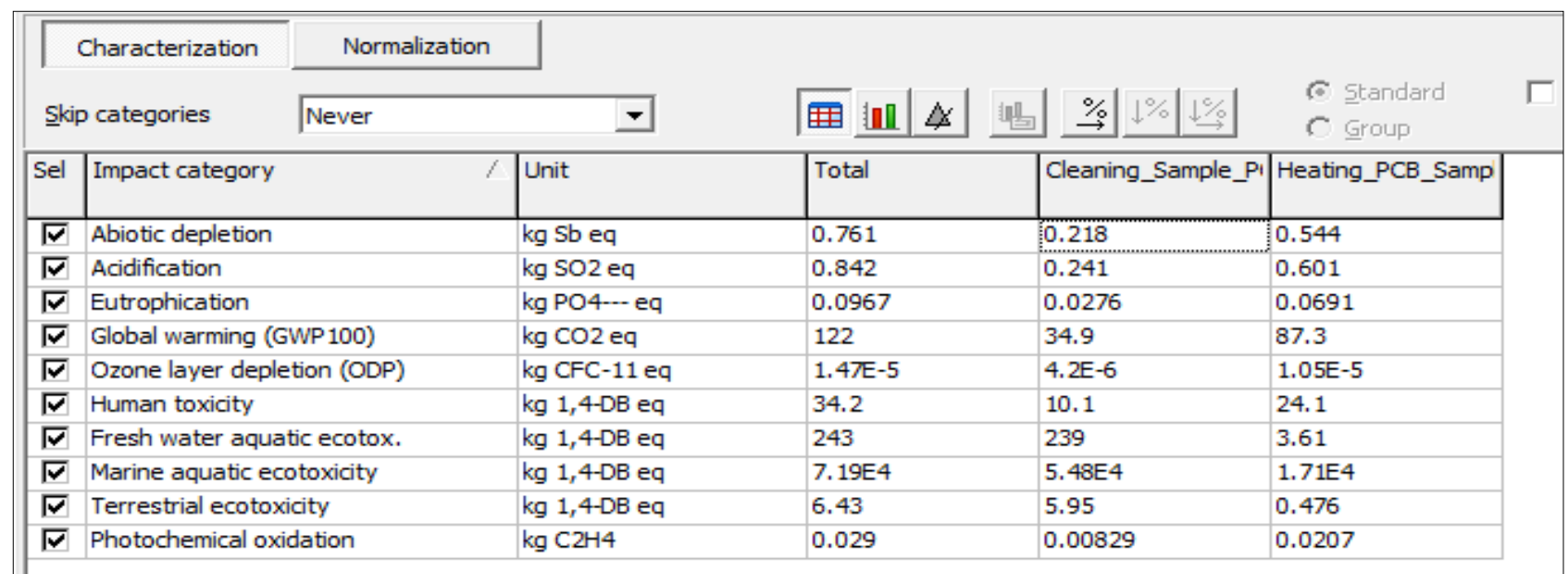

Fig. 4. Characterization result by impact categories using SimaPro

\section{CONCLUSION}

LCA is well known as a tool evaluating global environmental impacts because of its inherent characteristics to assess the environmental impacts including direct and indirect emissions of the substances related to environment.

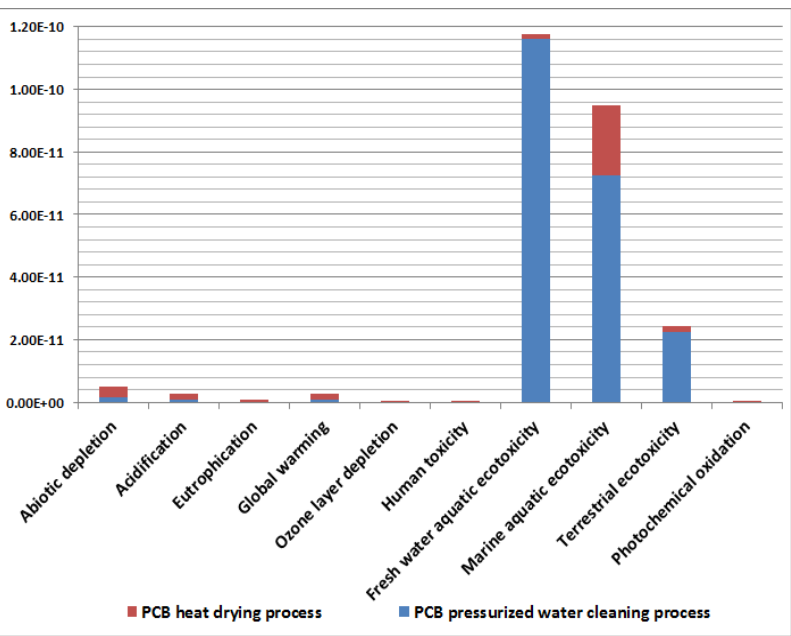

Fig. 5. Stacked normalization impacts by categories

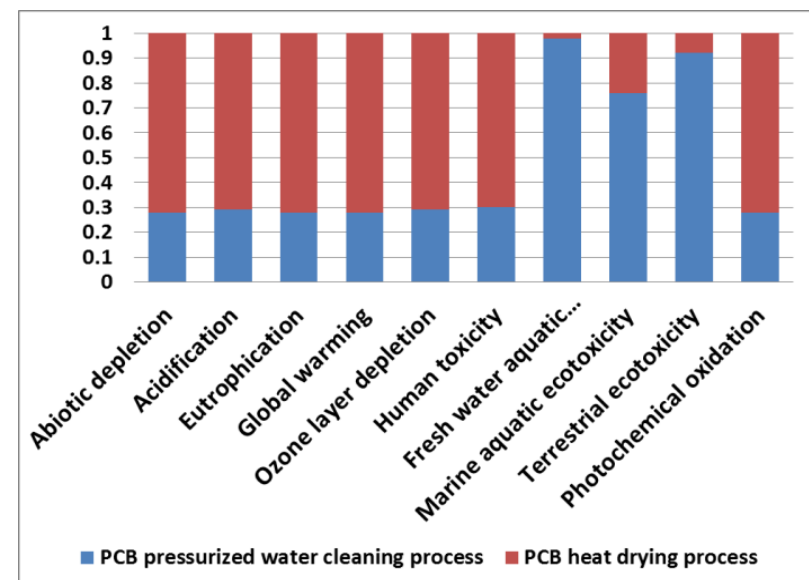

Fig. 6. Characterization impacts on the categories by two processes

In the pressurized water cleaning process, environmental load was high due to usage of cleaning water and emission of wastes like debris. Environmental load was high due to consumption of electric power for heating the oven system in the heat drying process. While most of FAET, MAET, and TET were produced from the cleaning process, most of the other seven categories except them were caused by the heat drying process.
The quantity of electricity consumption for post-drill cleaning process is one of the most important factors to affect the potential environmental impacts. In the future, the method will be investigated to improve thermal flow and prevent thermal loss to reduce the electricity consumption with quality of $\mathrm{PCB}$ retained through redesign of the oven system. The post-drill cleaning process is only a part of the whole processes for manufacturing PCB. If LCA is performed on the basis of more accurate data acquired from the entire processes, more reliable and meaningful results of LCA will be presented for decision-making for improvement of manufacturing processes in the viewpoint of environment.

\section{ACKNOWLEDGEMENTS}

This research was supported by the project, "Development of Information Technology-Based Manufacturing Process Systems for Energy Savings", one of international collaborative R\&D programs funded by the MKE, the Republic of Korea.

\section{REFERENCES}

[1] Sabine C.L.; Feely R.A.; Gruber N.; Key R.M.; Lee K.T. Bullister J.L. et al. (2004). The oceanic sink for anthropogenic $\mathrm{CO}_{2}$. Science, Vol. 305, No. 5682, 2004, pp. 367-371

[2] Feely R.A.; Sabine C.L.; Lee K.T.; Berelson W.; Kleypas J.; Fabry V.J. et al. (2004). Impact of anthropogenic $\mathrm{CO}_{2}$ on the $\mathrm{CaCO}_{3}$ system in the oceans, Science, Vol. 305, No. 5682, 2004, pp. $362-366$

[3] ISO 14040 (2006): Environmental management - Life cycle assessment - Principles and framework, International Organisation for Standardisation (ISO), Geneve

[4] Cooper, J.S. \& Fava, J. (2006). Life Cycle Assessment Practitioner Survey: Summary of Results, Journal of Industrial Ecology, Vol. 10, No. 4, 2006, pp. 12-14

[5] ISO 14044 (2006): Environmental management - Life cycle assessment - Requirements and guidelines, International Organisation for Standardisation (ISO), Geneve

[6] Kim S.T. (2003). A study on the application of Life Cycle Assessment for Combined Heat\&Power Plant, Master Dissertation, Konkuk university, Seoul, Korea

[7] Suh S. \& Gjalt Huppes. (2002). Messing inventory estimation tool using extended input-output analysis, International Journal of LCA, Vol. 7, No. 3, pp. 134-140

[8] Barbara Linke; Yu-Chu Huang \& David Dornfeld. (2011). Establishing Greener Products and Manufacturing Processes, unpublished

[9] http://www.kats.go.kr, (2006). Korean Agency for Technology and Standards,Trend of international standards, Accessed on 2006-07-03 